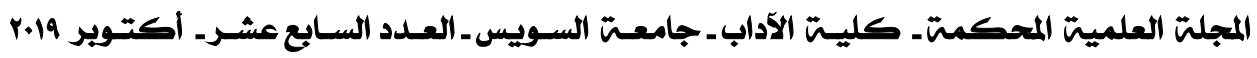

\title{
الإشاريَات في القصص النبوي دراسة تداولية
}

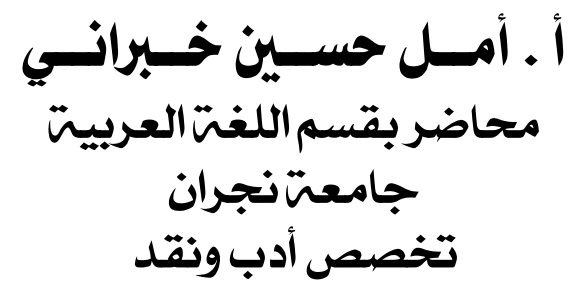




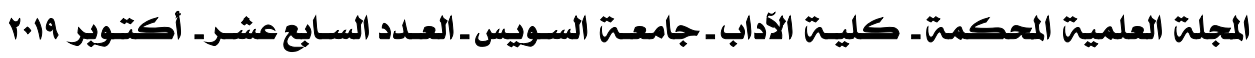


تُعدّ الإشـاريات إحدى المباحث الرئيسة في الــدرس التــداولي، وتــأتي أهميتها في اتفاق اللغويين على جعلها في الدرجة الأولى من درجات التداوليــة، إلـان.

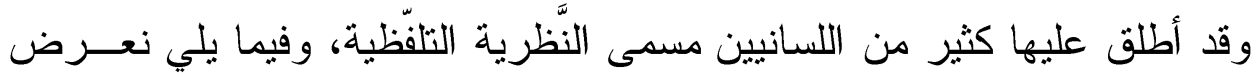

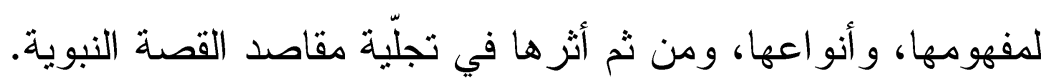

\section{أ ـ ماهية الإثاريات:}

الإشاريات مصطلح لغوي اختصّ به الحقل التداولي ويطلق على الصّيخ اللغوية التي تستعمل للقيام بالإشارة بواسطة اللغة، وقد عُرَت بأنهــا: "الأدوات التي نعتمد في فهنا لها على معناها الخاص، بل على إسنادها إلى شيء آخر" (').

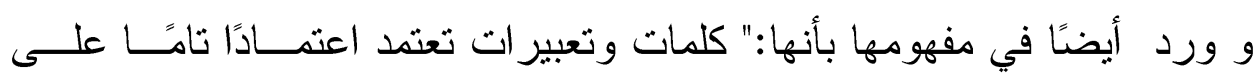

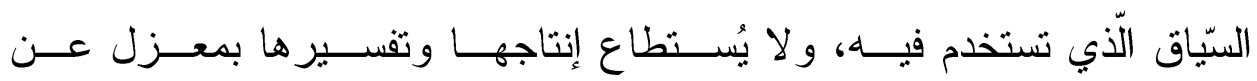

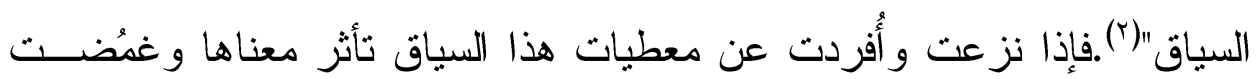
دلالتها، نظر اً لخلو ها عن أي معنى في ذاتها، ولهذا السبب كان النّحويون يُطلقون عليها اسم (المبهمات)(َ). و عند محاولة فهم مدلول هذه الصيخ في ذاتها يستدعي الأمر -في أبسط حالاته- معرفة المتكلم و المتلقي والإطار الزمــاني و المكــاني للحدث اللغوي. ولعل هذا الغموض الذي صاحب الإشاريات فـي معـزل عـنـ السيّاق جعل (لينسون) يُذّكر الباحثين النّريين في علم اللغة بأنّ اللغات الطبيعية

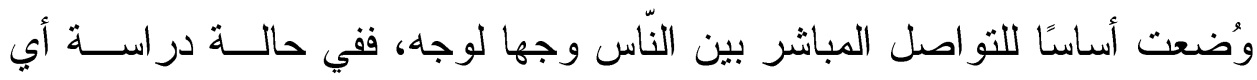
ظاهرة من هذا القبيل يجب دراستها داخل هذا الإطار و الأخذ بعــين الاعتبــار

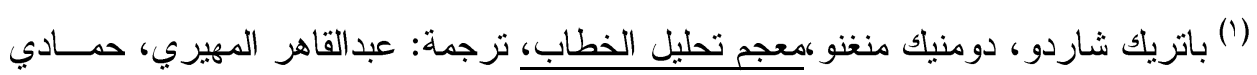

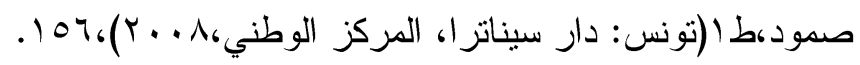

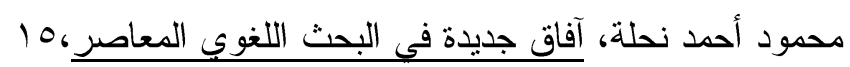

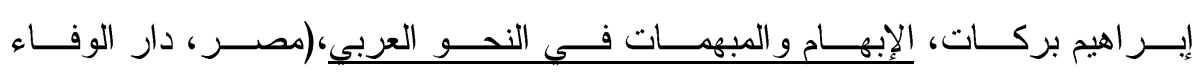

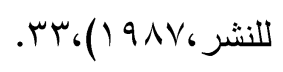


أطر اف العملية التواصلية و إلا استغلق الفهم وساد الغموض('). ويمكن أن نمشّلـل لهذا الأمر بالمخطط الآتي:

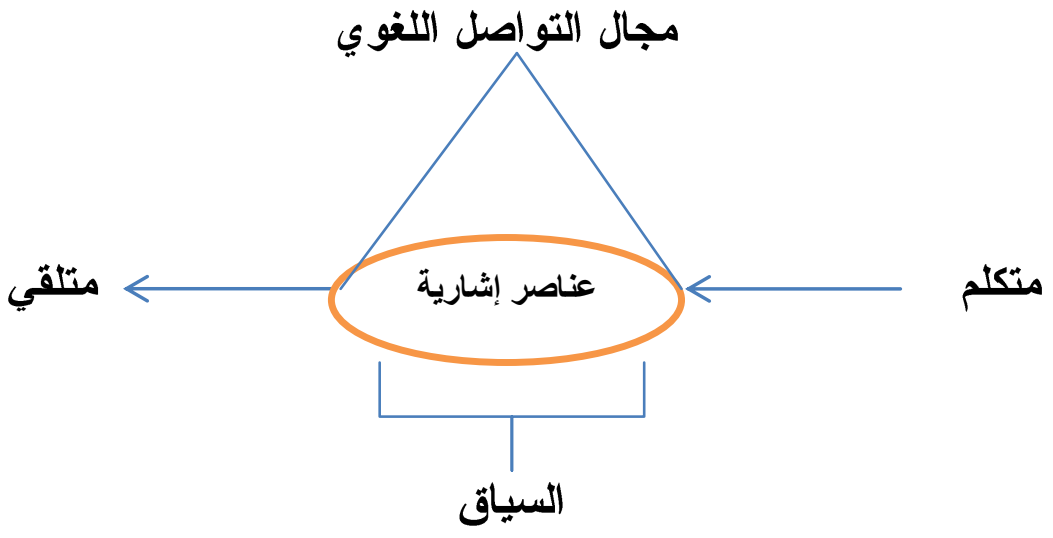

وتُؤدي الإشاريات مهمّة التّعيين وتوجيه الانتباه إلى موضو عها بالإشارة

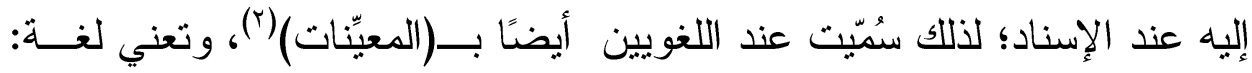

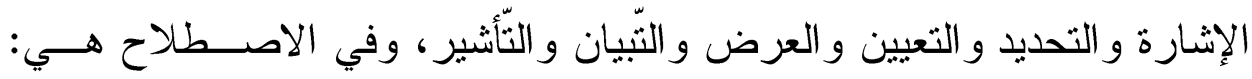

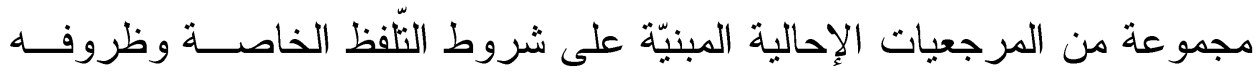
كهوية المتكلم ومكان التلفظ وزمانه.

تقوم الإشـاريّات على دراسة عناصر إنتـــاج الخطـــاب اللغـــوي التــي تحصر ها في: (الأنا) ، (الهنا) ، ( الآن)، ويقصد بــ(الأنا): المتكلم الذي يصدر

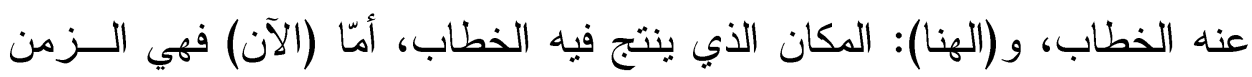

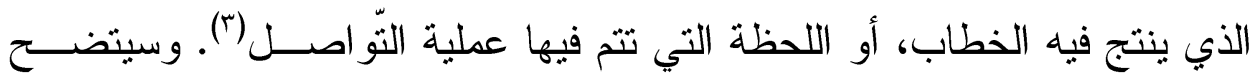

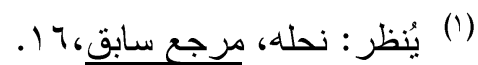

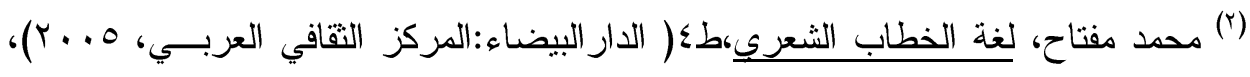
.101

يُنظر : نادية رمضان النجار ، الاتجاه التداولي و الوظيفي في الدرس اللغوي،ط ( مؤسســة

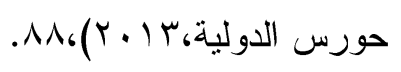


تفصيل هذه العناصر عند عرض أنواع الإشاريّات. ويتتــاول اللســانيون هـذذا المبحث التداولي وفق ثلاثة تصور ات حددها(سو الو) كالآتي ('): ا-دراسة الإشارية من حيث كونها ترد أثياء العالم وأحداثه إلى الموقع الــذي يحتله المتكلم في المكان وفي الزمان، و لأنه يوفر إمارة لمرجع قد تكون بعد. r- الإشارية من حيث كونها نمط تركيبي مرجعي لا يفصل بين الجهة و الحدث. ب- الإشارية من حيث كونها عامل تناسق نصي (محورة، تبئير) تُمكن من إدخال أشياء جديدة في الخطاب.

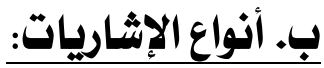

يكاد يجتمع رأي الباحثين في مجال الدرس اللغوي على أن الإشــاريات التداولية خمسة أنواع هي: إثـاريات شخصية، و إثشاريات زمانيــة، و إثـــاريات

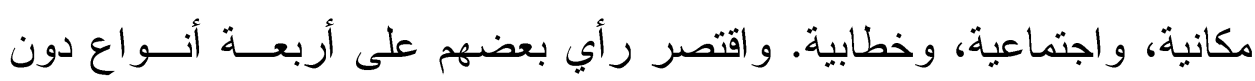

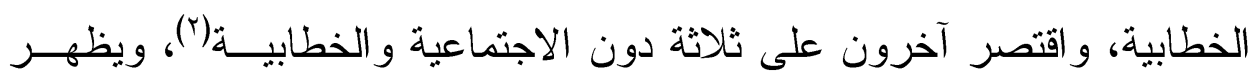
التفصيل في أنو اعها على النحو الآتي: ب-1 الإشاربات الشخصبة :

يُقصد بها العناصر الإشارية الدالة على شـــص مــا، وتشــل هـــه الإشاريات ضمائر المتكلم في حال الإفر اد و الجمع: ( أنا، تــاء المــتكلم، يــاء المتكلم، نا الدالة على الفاعلين، نحن)، وتشمل أيضًا ضـــــائر المخاطـب فــي الإفر اد، و التثنية و الجمع للمذكر و المؤنث على حدٍّ سو اء: ( تاء المخاطب، أنت، أنتِ، أنتما، أنتن، أنتن)، وكذلك الحال في ضمائر الغياب و ورودها بجميع الصيغ للمذكر و المؤنث، ويشترط في هذا النوع من الضمائر أن لا يعرف مرجعها فـي وي وني السياق اللغوي؛ لأن وظيفة السياق التداولي تتمثل في معرفة إثارة هذه الضمائر

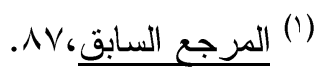

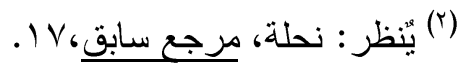


إلى مرجعها، فإن ظهر مرجع هذه الضمائر في سياقها اللغوي خرجت من حقل الإشاريات التداولية ـ ـ ويدخل النداء في الإشاريات الشخصية، لتضمّنه الإشــارة

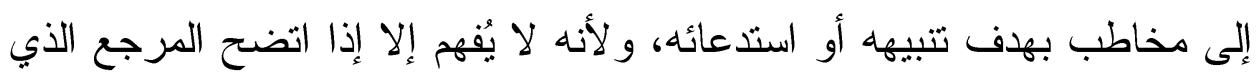
يشير إليه ('). وقد يبدو للارس من أوّل وهلة أنّ الحديث عن الضمائر و أنو اعها هــو من خصائص الدرس النحوي الذي يهتم بالنواحي التركيبية للجملة، وهـــا أمــر

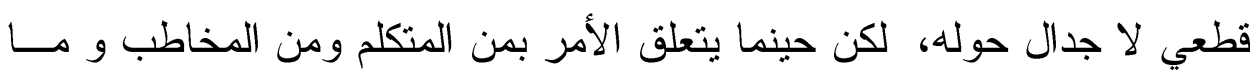
تكتسبه تلك العناصر من معانٍ جديدة مقصودة ومختلفة في كل استعمال لغوي لها وبحسب المقام الذي يجري فيه التو اصل يُصبح الأمر هنا من صـــيم الــدرس التداولي. ولتوضيح هذا الأمر سنعرض أمثلة تطبيقية عــن هــذا النــوع مــن مئن

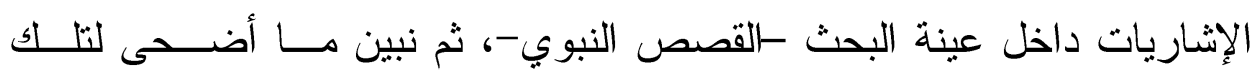
العناصر من معاني إبداعية أَتَّتها لغة القص مما دعّم وظيفتها التو اصلية. ويأتي التطبيق عليها من خلال التفصيل في عناصر الإشاريات الشخصبة كالآتي: ب-1-1 الضمائر:

تتقسم الضمائر إلى ضمائر وجودية وضمائر ملكية. وترد جميعا بصيغة المتكلم و المخاطب و الغائب. و الضمائر الوجودية الدالة على الذات نحـــو : أنــا، وأنت، ونحن، وهو، وهما، وهن ، وهم... . و الملكية نحو: كتـابي، كتـابكم ، كتابنا، كتابهم، كتابهن و هكذا. و قد ورد بعض من هذه الضـــمائر فــي القصـــة النبوية المعنونة بــ(جرّة الذهب) حيث جاء في صحيحي البخاري ومسلم الحديث

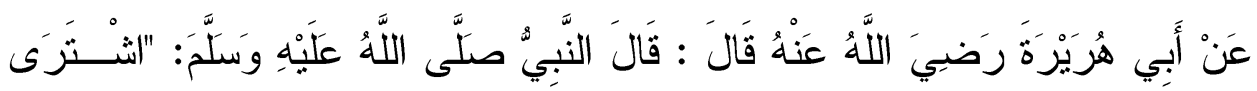

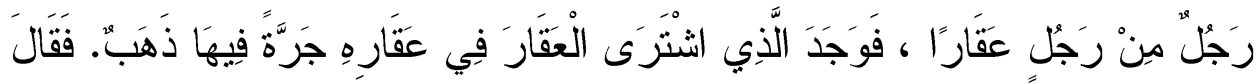

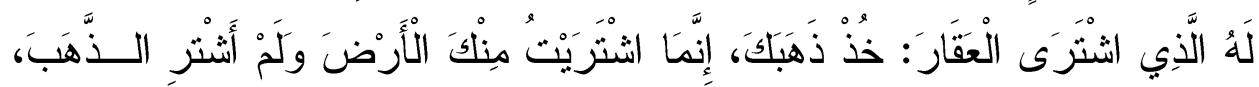

(1) ينظر : نحلة، مرجع السابق، 19. 


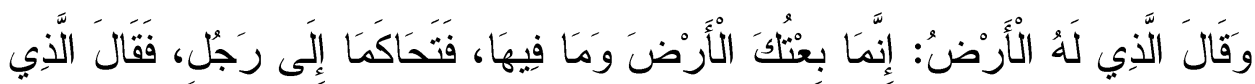

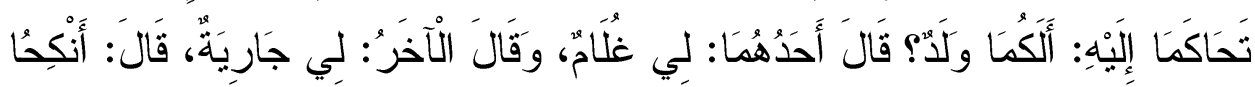

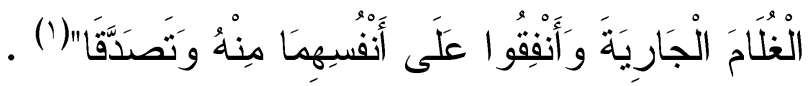
المتأمل للضمائر الشخصية التي احتوت عليها القصة ترد أغلبها في صــيغتي ضمير المتكلم ( أنا) و المخاطب( أنت، الكاف، أنتما)، وضمائر الغياب(هو، هما) وتشير جميعها إلى الثّخصيات التي جرى بينهما الحوار فـي القصـــة، وهـي: شخصية الرجل الذي اشترى العقار ، وشخصية الرجل بائع العقــار، و كـــلك شخصية الرجل الحكم بين الطرفين • ويمكن تلخيصها بالجدول الآتي:

\begin{tabular}{|c|c|}
\hline نوع الضمير & المُشُار إليه \\
\hline 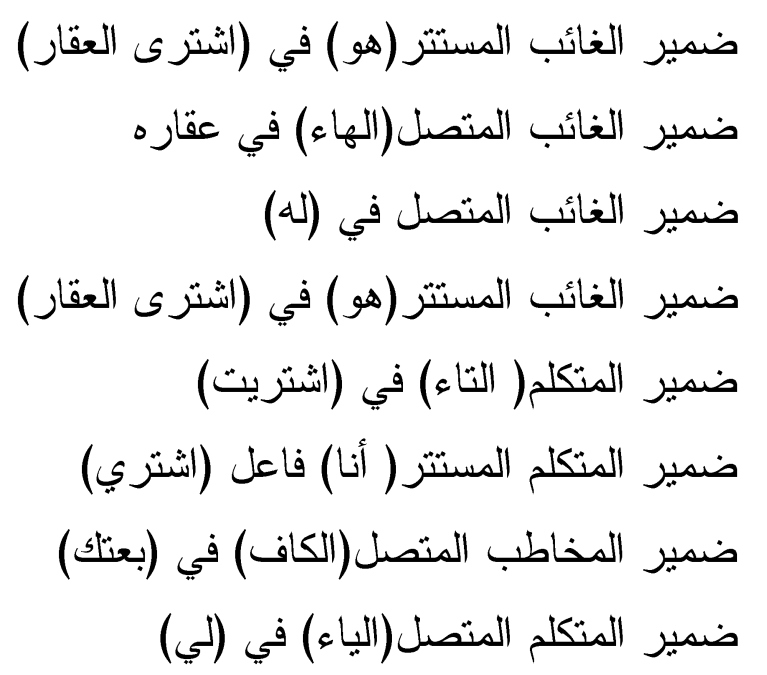 & الرجل المشتري \\
\hline 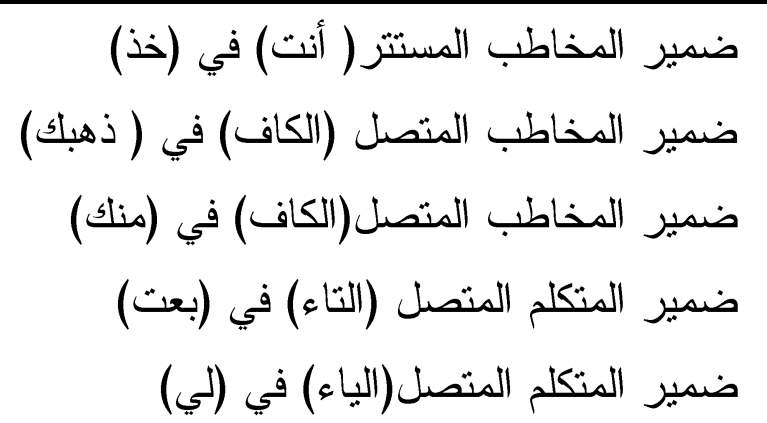 & الرجل البائع \\
\hline
\end{tabular}




\begin{tabular}{|c|c|}
\hline نوع الضمير & المُشّار إليه \\
\hline - - - ضمير الغائب المستتر( هما) في (فتحاكما) & الرجلان معا \\
\hline - ضمير الغائب المستتر (هو) & الرجل الحكم \\
\hline
\end{tabular}

يُلحظ في الجدول أعلاه أن جميع ما ورد من الضمائر في القصة النبوية السالفة مع تكرارها تشير إلى شخصية الرجل الذي اشترى العقــار، وشخصـــية الرجل الذي باع العقار، وما ورد من تثنية في الضمير المستتر (أنتما) تشير إلى إنى تلك الثخصيتين مجتمعتين، وبالتالي فإن هذا التكرار لنفس الضمائر يدل على أن تلك الثخصيتين اتخذت موضع محورة وتبئير في مجال التو اصل اللغوي داخل القصة من خلال تكرار الإشارة، إليهما، الأمر الذي لفت انتباه المتلقي إلى القصد

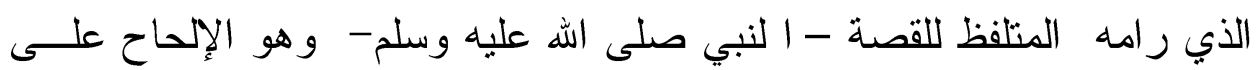
ضرورة التحلّي بالورع و الزهد و الحكمة في المعاملات، و الحرص على التمسك بأخلاق الإسلام وتعاليمه مهما كان الأمر، و هو ما تميزت به الشخصـــيتين فـي القصة.

ولعل تكرر الإشارة إلى شخصية الرجل المشتري أكثر مــن الإشــارة لشخصية الرجل البائع يعطي ترجيحًا بأفضلية الأسبق في مجال الخيـر، حيـــث

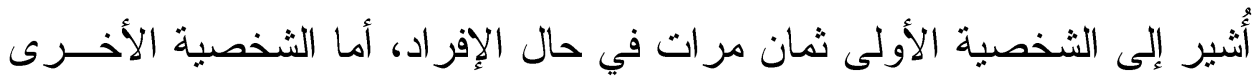

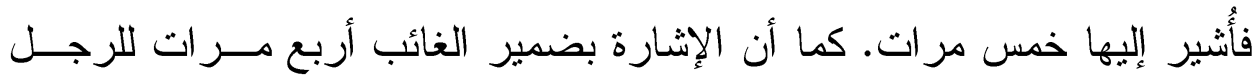
المشتري داخل سياق القص من قبل المتلفظ يرجّح التفضيل لهـــه الشخصــية.

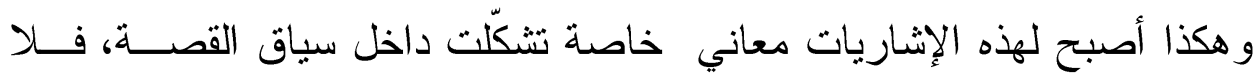
يمكن أن تؤدي المعنى ذاته إذا انتزعت أو وُظفت في سياق آخر. 


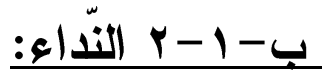

ويصنّف ضمن الإشاريات الشَّصية، لأنه يُشير إلى الشخص المخاطب

من أجل تتبيهه أو توجيهه أو استدعائه، و قد ظهر النّاء في مواطن كثيرة مسنـ القصص النبوي، و اخترنا منها القصة التي تحكي عن طهع ابن آدم، فورد عَـنـن

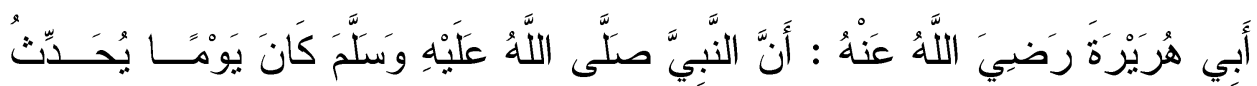

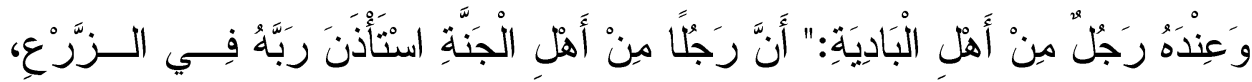

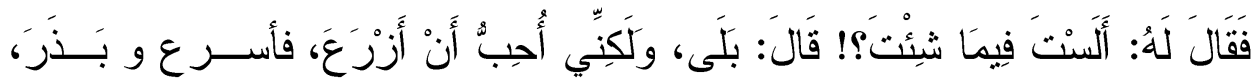

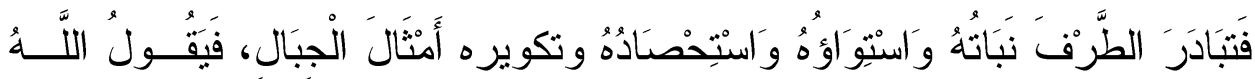

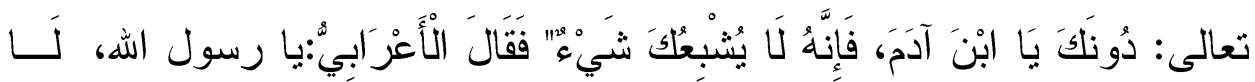

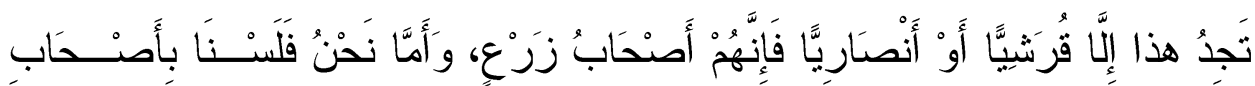

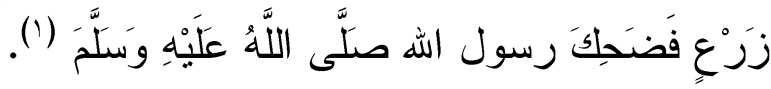
اختصّ النداء في القصة النبوية السالفة بشخص بني آدم (يا ابــن آدم) ، الذي كان أحد العناصر الرئيسة و الموجه له الخطاب في القصة، فجـــاء اللفـــ بتوظيف (ياء) النداء وهي للبعيد، و ومناداة (ابن آدم) بهدف التتبيه و الإشارة إليه. و المتأمل للشخصيات الرئيسة داخل القصة القائم بينهـــا الحــــوار (الــذات الإلهية- الرجل) يجد أن شخصية الرجل الذي استأذن ربه في البداية شخصــية

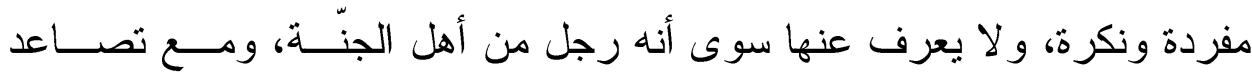
الحوار القصصي وتوظيف النداء تحولت الشخصية ذهنيًا مــن حــال الإفــراد و التخصيص إلى التعميم حينما نُودي بــ(ابن آدم) دون أن يُحدث ذلك خلل فـي سباق القصّ اللغوي ، حيث أثنار النّاء إلى تلك الشخصية-الرجل الذي اسـتأذن ربه- بمنتهى الوضوح من غير إلباس على المتلقي في مستوى الفهم. وتبـــرز 
أهمية مؤشر النداء في إجلاء الغرض من القصة وهو التتبيه إلى فضل القناعــة وذمّ الطمع حتى وإن جُبلت النفوس على حبّ الاستكثثار إلا ما شاء الله ('). و قد حقق مؤشر النّاء التكامل و الالتحام النصّي بين اللفظ و المعنى داخل السياق القصصي السابق، فاللفظ فيه يختص بشخصية الرجل الموظفــة داخــلـ القصة، و المعنى ينساق على بني آدم جميعهم باعتبار ذلك الأمر غريزة فـــهم ، و هذا من البلاغة اللغوية في القصص النبوي الشريف.

\section{ب-ب الإشاريات الزمانبة:}

يقصد بها كل صيغة لفظية تشير إلى زمن معين يحدده الســياق، قياستــا

على زمن التّكلم الذي يشكل مركز الإشارة الزمانية في الكلام. ويعني ذلك أننــا أمام زمنين في الخطاب الأول هو زمن التلفظ/التكلم، و الآخر إثارة زمنية فـي الخطاب مرتبطة في فههها بالزمن الأول الذي يُشكل مرجعيــة لفهـم الســياق اللغوي، وإلا التبس المرجع الذي يُحال إليه وهو ما يعــرف بــالمركز الزمنــي

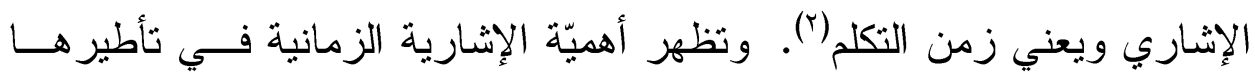
لعملية التواصل داخل نطاقها الزمني، نظر الكونها تعبّر عن اندماج المــتكلم و المخاطب أو المتلقي داخل الزمن النصّي و التلفظي والتو اصلي (r)، فإن لم يُعرف زمن التكلّم التبس الأمر على المتلقي وتعسرّ الفهر والتواصل(؛).

(') يُنظر :أحمد بن علي بن حجر العسقلاني، فتح الباري شرح صحيح البخاري (دار الريــان

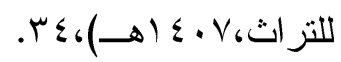

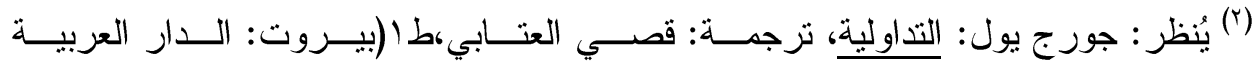

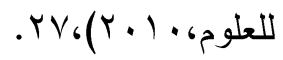

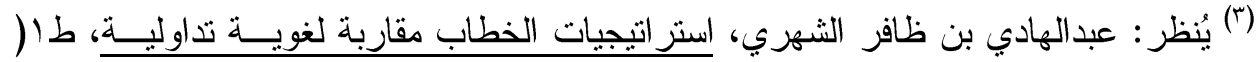

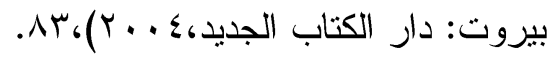

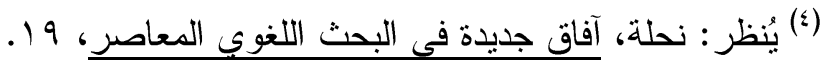




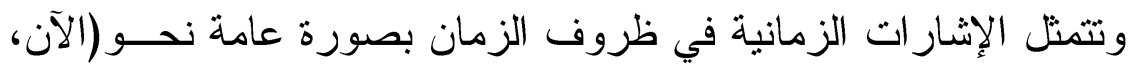

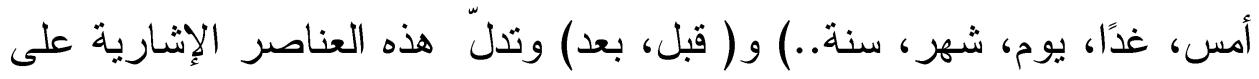
الزمان الكوني وهو ما يشمل السنين والأشهر والأيام، أمّا الزمان النّحوي فهو

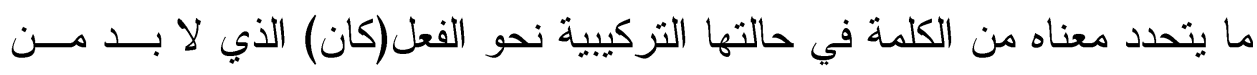
الإشارة إلبه بعينه في زمن التكلم ، وقد يُفهم الزمن من السياق اللغوي وفق مــــا يدل عليه زمن التكلم، كصيخ الأفعال في حال المضي و المضار عة و المستقبل. و في إطار الحديث عن القصص النبوي نجد أن هذه الإشاريات الزمانية قد ظهرت بنو عيها في المتون القصصية، وكان لها أثز ها في إيضـــاح المعنـى و إفهام المتلقي وإيصال القصد، لا سيما أن هذه الأدوات عملت على ثر ابط النص القصصي وهو ما سيّلحظ أثناء التحليل. ومن أمثلة الإشاريات الزمانية ما ورد في قصة أصحاب الغار الثلاثــة

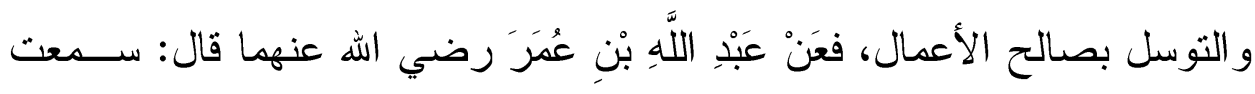

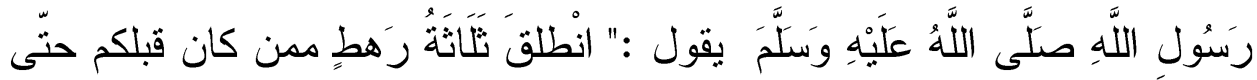

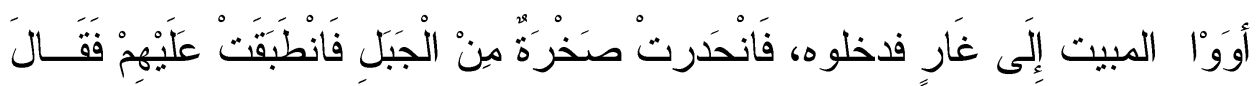

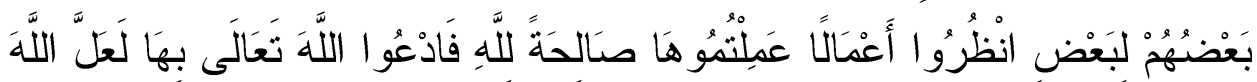

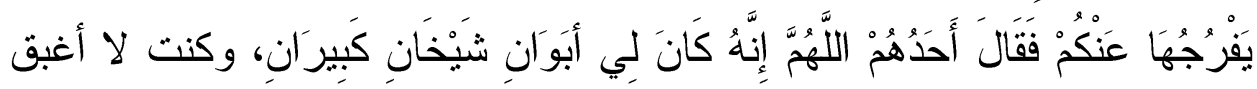

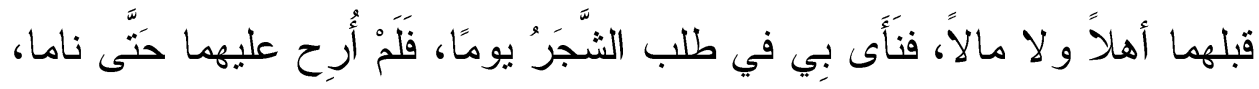

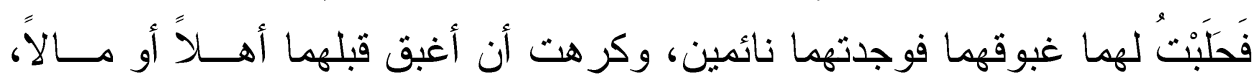
فلبثت و القدح على يََيّ أنتظر استيقاظهما حتّى برق الفجر، فاسـتيقظا فشــربا

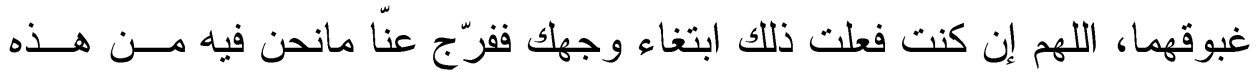
الصخرة، فانفرجت شيئًا، لا يستطيعون الخروج.

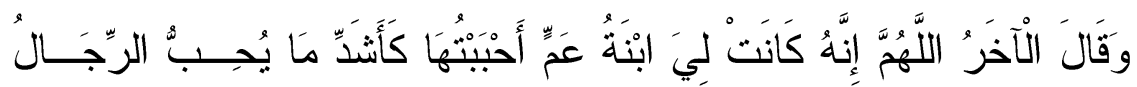

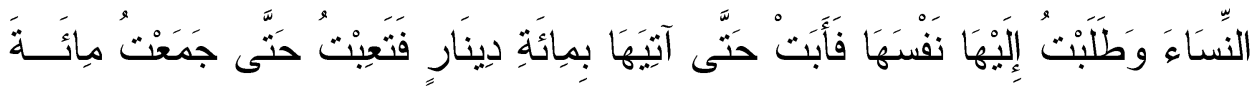




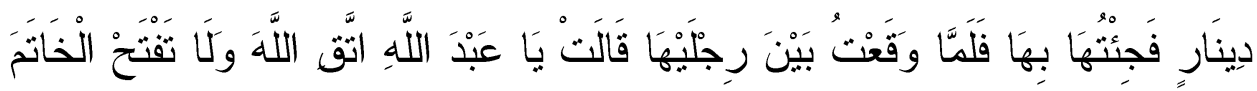

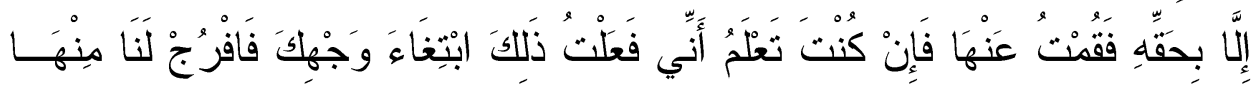

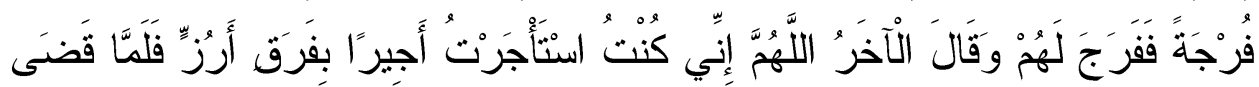

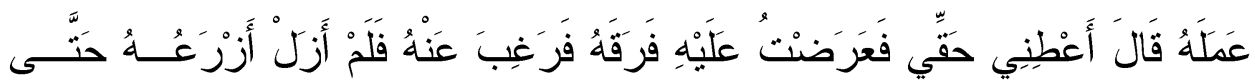

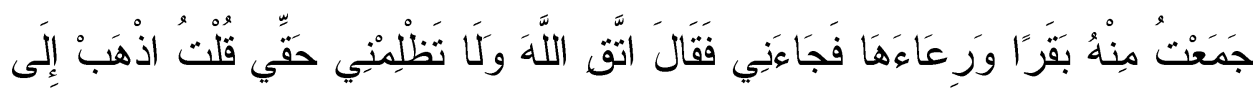

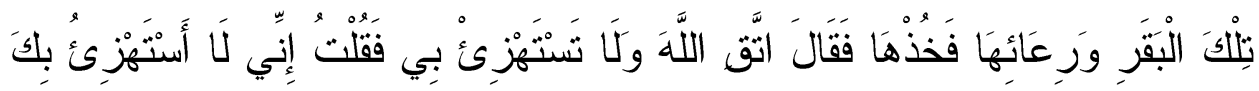

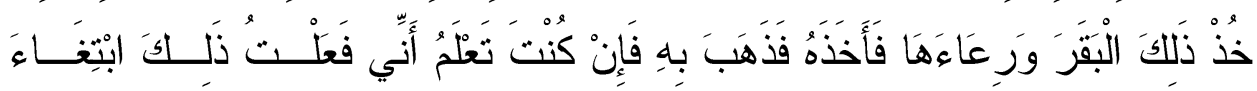

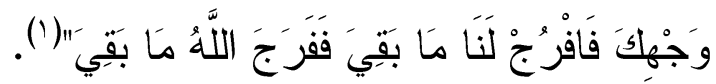

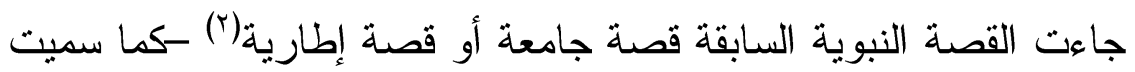

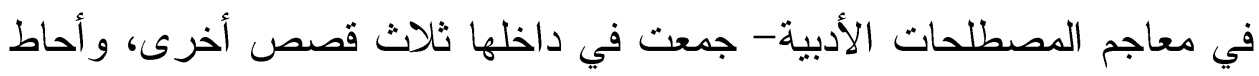

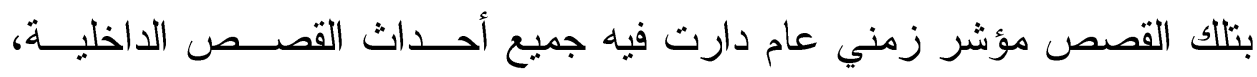

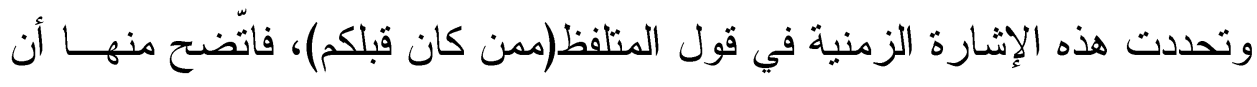

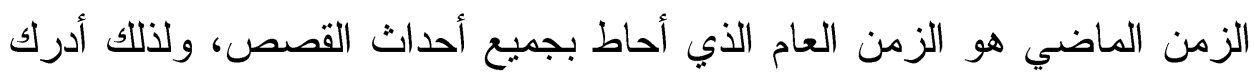

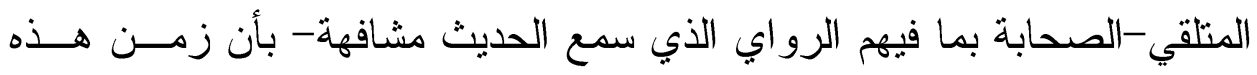
القصة يعود إلى فترة سابقة قياسًا بالزمن الحاضر الذي يعيشونه أثناء التواصل

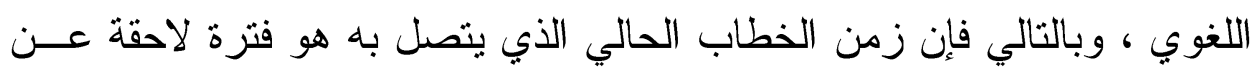

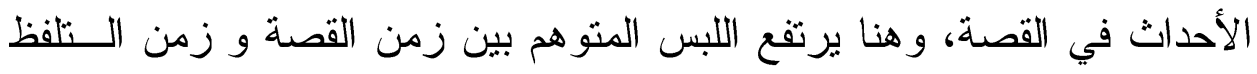

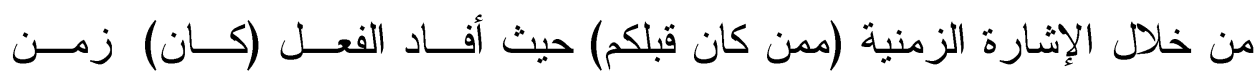

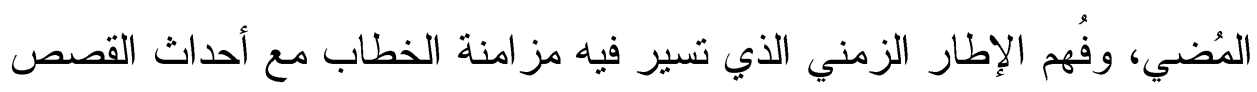

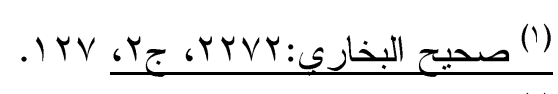

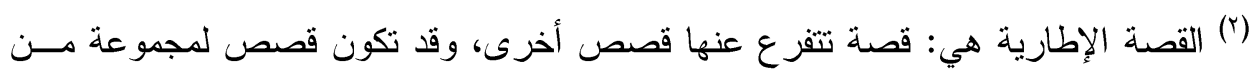
الرواة يتتاوبون على حكايات القصص بداخلها. يُنظر : معجم المصطلحات العربية في اللغة ولة

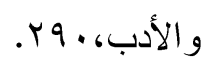




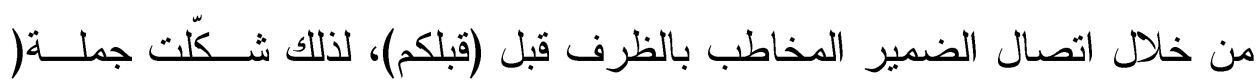
ممن كان قبلكم) المركز الإشاري في قصة أصحاب الغار . وبما أن للقصة مؤشر زمني عام وهو المدلول عليه بالفعل (كان قــبلكم) و هو كما سبق تعريفه بأنه المركز الزمني الإشاري ، فإن هناك مؤشــر خــاص لكل قصة من القصص، ويمكن أن نوضح لها بهذا الجدول :

\begin{tabular}{|c|c|c|c|}
\hline العدد & نوعها & الإشارية الزماتية & القصة \\
\hline & 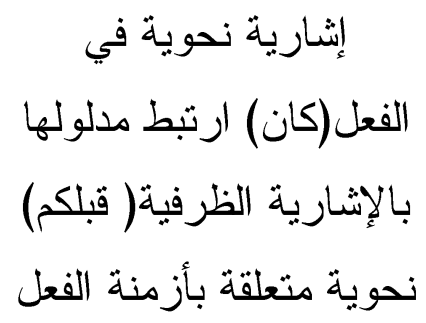 & 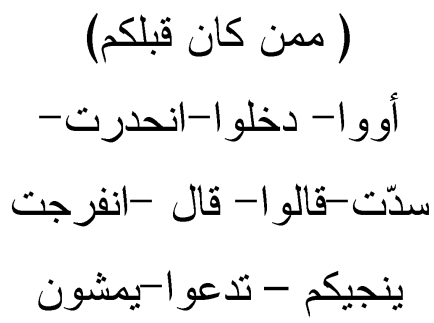 & أصحاب الغار \\
\hline$r$ & زإثارية نحوية زمارية نحوية نحوية نحوية نحوية نحوية نحية & كان لي & البر بالو الدين \\
\hline r & 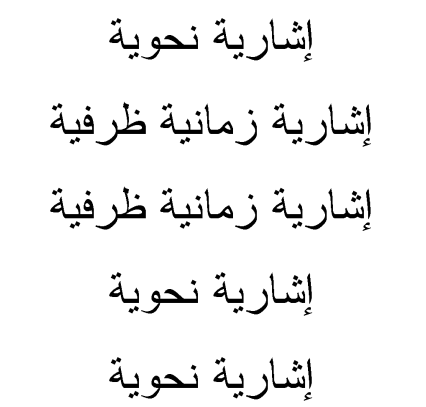 & سنة كانت & العفة عن \\
\hline
\end{tabular}




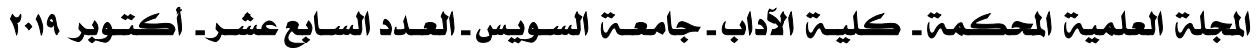

\begin{tabular}{|c|c|c|c|}
\hline العدد & نوعها & الإشـارية الزماتية & القصة \\
\hline & إشارية نحوية & فعلت & \\
\hline & إثارية نحوية & استأجرت & حفظ الحقوق \\
\hline & زمانية ظرفية & حين & \\
\hline & نحوية & كنت & \\
\hline & نحوية & فعلت & \\
\hline
\end{tabular}

اتضح من الجدول السابق أن أغلب الإشاريات الزمنية جاءت من قبيـلـل

الإنشاريات النحوية التي عبّرت عن زمن الأحداث بصيغة الفعل الماضي (كـان،

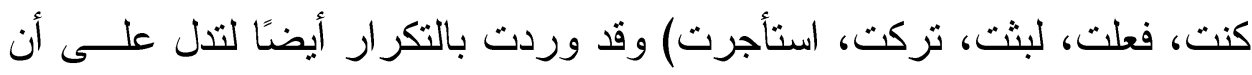

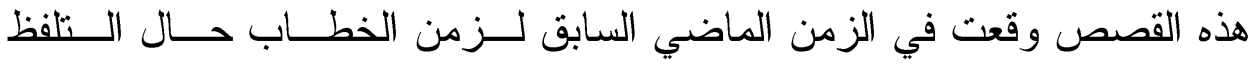

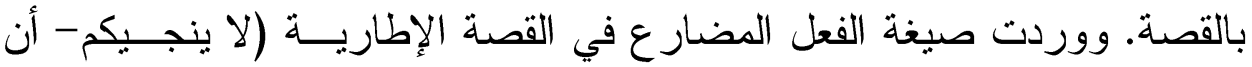

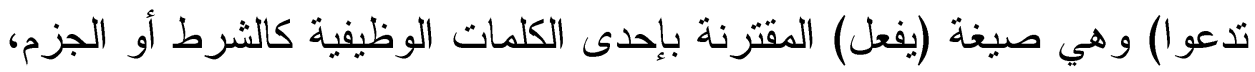

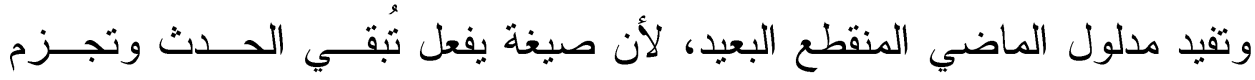

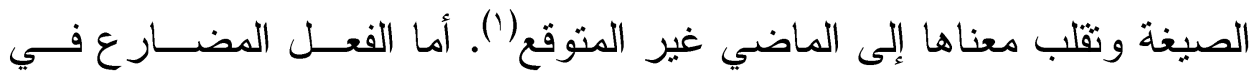

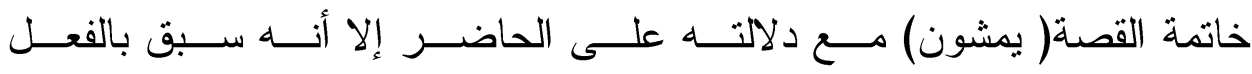

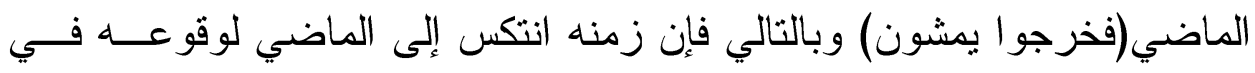
مقول مستهلاً بالفعل الماضي. وقد تكررت اللازمة الزمانية النحوية(كنت فعلت) في القصص الثلاث التي قطعت بإثبات الزمن الماضي لأحداث القصّ المتضمنة

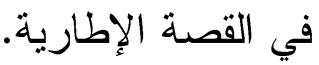

(') بنظر : محمد عبدالرحمن الريحاني، اتجاهات النحليل الزمني في الدراسات اللغوية، (مصر :

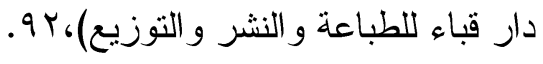


وقد ظهرت مؤشر ات زمانية ظرفية في قصة (البرّ بالو الدين) نحو (يوماًالفجر) ووقت الرواح آخر النهار و الذي فهم من صيغة الفعـل الماضــي(أرح). وكذلك قصة (العفة عن الحرام) جاء فيها مؤشرات زمانبة( سنة-سنين - حين). وبما أن القصص جميعها قد وقعت في زمن ماضٍ عن زمن الــتلفظ إلاه

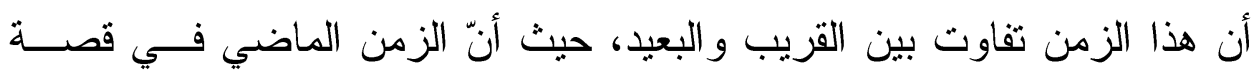
أصحاب الغار الذي بدأ بانطلاق ثلاثة رهط ممن كانوا في زمن ماضي عن زمن التلفظ يُعدّ ماضيًا قريبًا عن الزمن داخل القصص الثلاث.

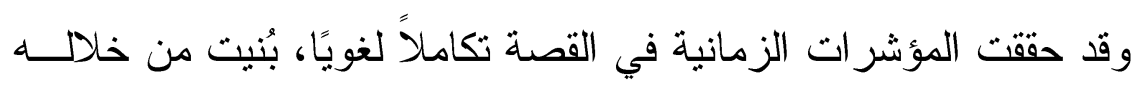

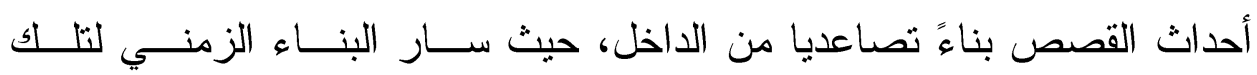

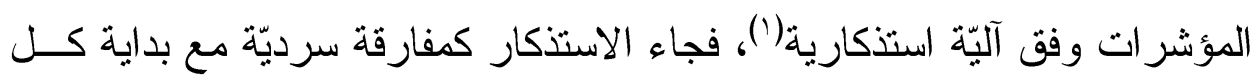
قصة ، إذ يذكر كل شخص من الرهط الثلاثة عمله الصالح وفق مؤشر زمنـي نحوي:(كان لي أبوان..)و (كانت لي بنت عم...)و (إني اسـتأجرت أجــراء..) وتعود هذه البدايات الاستذكارية إلى زمن مجهول غير محدود يتجــاوز نقطـــة انطلاق القصة التي تبدأ أحداثها بخروج الأشخاص الثالثة، وبالتالي فإن المسافة الزمنية التي يمثلها الاستذكار بالنسبة إلى زمن القصة الإطارية و اضحة ومحدة

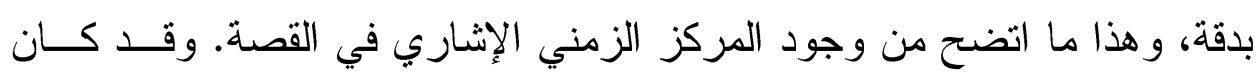

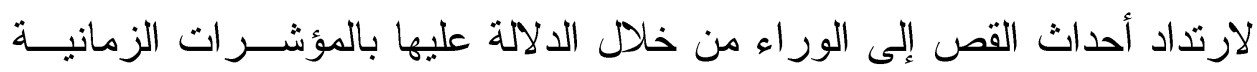
النحوية المتمثلة في صيخ الأفعال الماضية أثر في تحديد المسافة الزمنيــة بــين

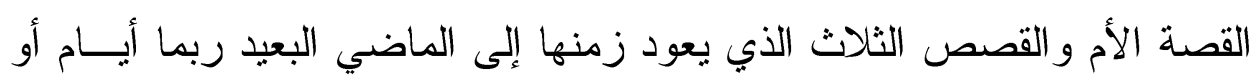
سنوات، وهو ما يستغرق مسافة زمنية عن زمن القصة.

(') الاستذكار هو: الاسترجاع في السرد أو العودة إلى الوراء عند (جينيت)، والإخبار البعدي

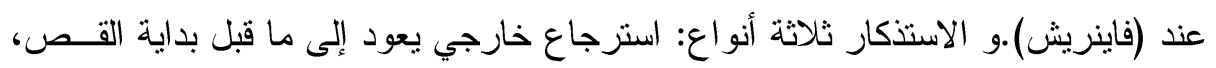

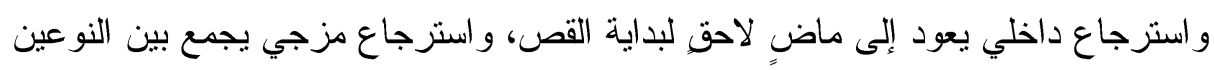




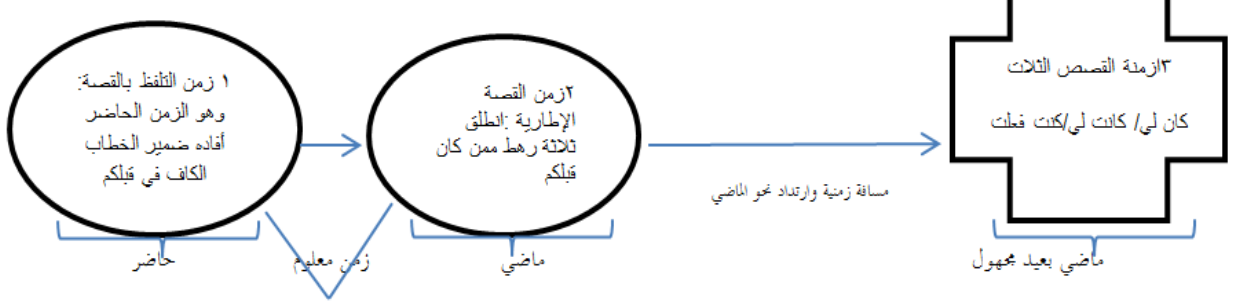

مخطوطة توضع سير الإثـارية الزمانية في قصة أصحاب الغار

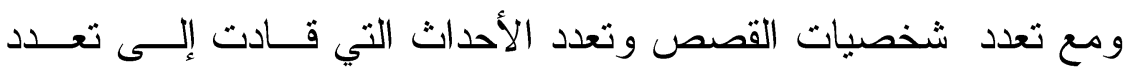
محاور المؤشر الزمني في القصة إلا أن المتلقي بمعرفته لمركز الزمن الإشاري استطاع أن يحيل باقي المؤشرات الزمانية على هذا المرجع، وتمكن كذلك مــن

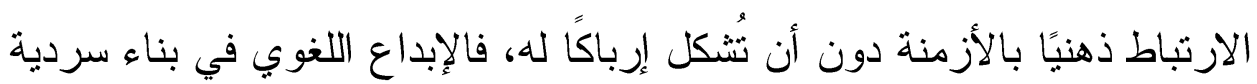

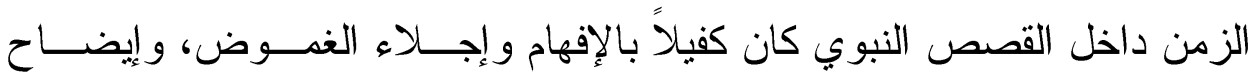
الهدف من القصة وهو أنه مهما امتّّ الزمن بالإنسان فحليه التوسل إلى الله بصالح

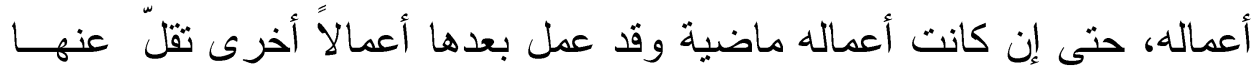

\section{ب-ب الإثاريات المكانبة:}

هي صيخ لفظيّة تدل على مكان ما، فإمّا أن تكون أسماء لأماكن محددة، و إمّا أن تكون من ظروف المكان، نحو: هنا ،هناك، فوق، تحت، يمـين..إلخ، و إما أن تكون أسماء إثارة نحو: (هذا، هذه، ذلك، هناك )إذا أشارت إلى المكان. ويبقى تفسير استعمال المؤشرات المكانية منوطًا بمعرفة الظروف المحيطة بسياق

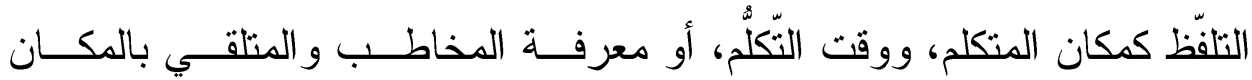
المقصود في الخطاب أثناء التو اصل اللغوي(')، وهذا ما يعرف بالمركز الإشاري 
للمكان، فمن الصعب أن يُفهم معنى هذا و هذه أو هنالك ويمينــا وشــمالا مــالم يعرف مكان المتكلم و وقت التلفظ('). و القصص النبوي ضمّ في متونه الشريفة الإشاريات المكانية ،كونها من الأدوات التي تشهم في عملية الربط بين أجزاء النص، ناهيك عن اعتبار المكان

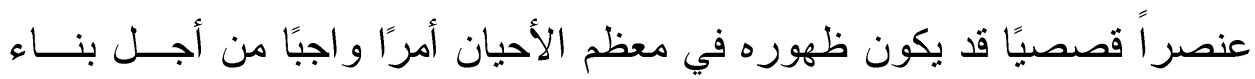
الحدث القصصي، ولعله ظهر بقوة في قصة أصحاب السفينة الواردة في الحديث

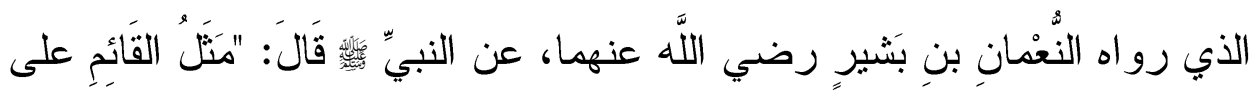

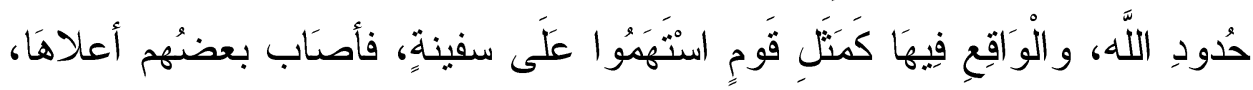

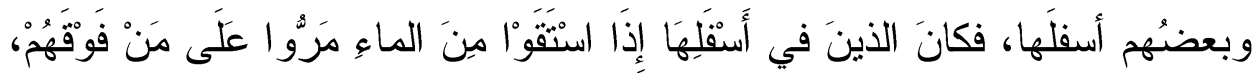

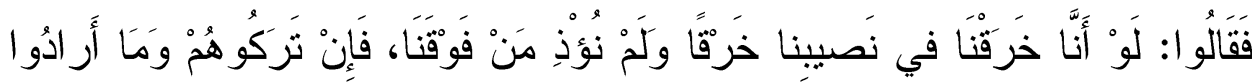

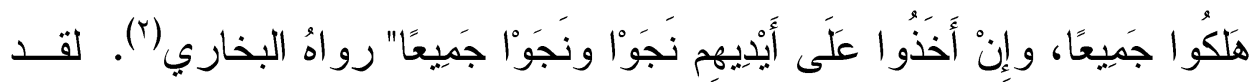
جاءت الإشارة المكانية في القصة على نوعين: الأولى بالتسمية، وهي في القصة و اضحة ومحددة المعلم وهي السفينة، والنوع الآخر جاء مــن خــلال الإشــارة بالظرف المكاني، نحو: (أعلاها، أسفلها، فوقهم) وهي إثاريات لا يمكن أن تفهم إلا من خلال السياق، حيث يتحدد المقصود بها أثناء القصّ استتاداً على معرفــة المركز الإشاري للمكان وهو السفينة، كونه اتضح للمتلقي بمجرد تحديــده فـي

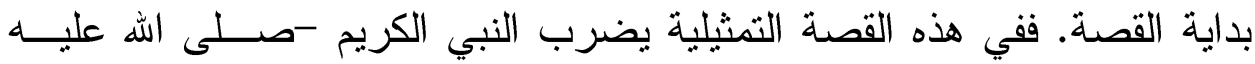
وسلم- مثناً للقائم بحدود الله و المنتهك لها، بجماعة صعدو ا على سفينة و اتّذذ كل هل منهم مكانه وفق تخطيط سابق، فكان الذين في أسفل الســفينة إذا أر ادوا المــاء صعدوا إلى الأعلى ومروا على من فوقهم فوجدوا حرجًا من إيذائهم، فرأوا أنهم إذا خرقو ا مكان وجودهم في أسفل السفينة و أخذو ا ماءً أراحوا من فوقهم، لكـنـ

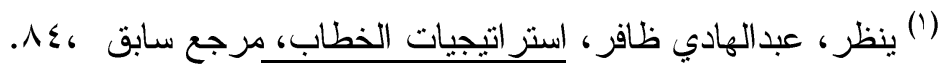

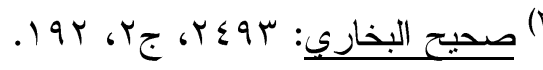


الذين فوقهم إن تركوهم هلكو ا جميعاً، و إن أخذوا على أيديهم نجوا جميعاً. فبمـــ

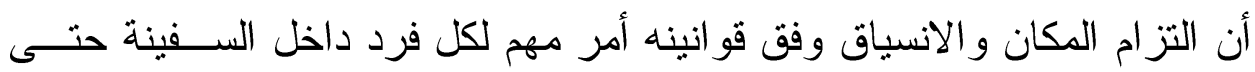
تتحق النجاة في رحلة الإبحار ؛ فإن الالتز ام بأوامر الله متطلب هام للنجـــاة فـي الحياة ، ومخالفتها تقتضي الهلاك فورا حتى وإن تذرّع البعض بذرائع المصلحة أو المنفعة الشخصية. وقد بدا للإشاريات المكانية أهمية بارزة في لغة القصة السابقة؛ وذلـــك

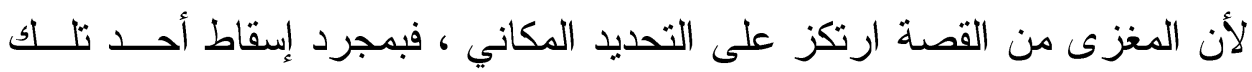

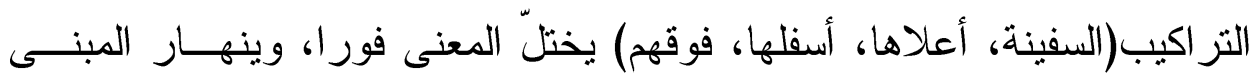
القصصي، وبناء عليه جاء النسيج اللغوي للقصة قائمًا بشكل تام علــى المكـــان المُشار إلبه من خلال الوصف و الظرفية.

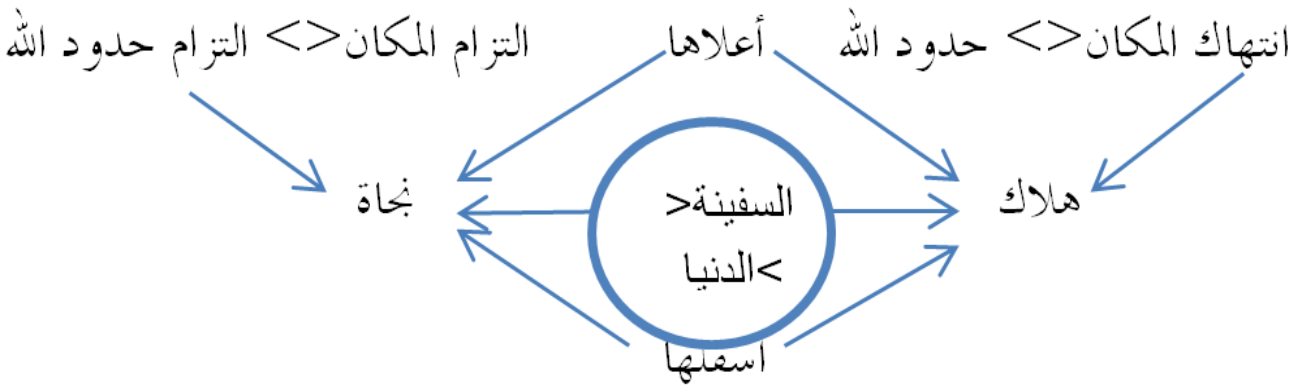

مخطط يوضح مدلول الإثاريات المكانية في القصة

\section{ب- بـ الإشاريات الإجتماعية:}

هي ألفاظ تشير إلى العلاقة الاجتماعية بين المتخــاطبين، وتتقســم إلـى إثاريات تدلّ على علاقة رسميّة بين المتكلمين، و إثشاريات غير رسمية تدلّ على الهى سمات في العلاقات كالألفة و المودة ونحوها('). وفي الإشاريات الرسميّة تظهـر وسئر الصيغ الدّالة على التبجيل و التي تر اعي المنزلة و الطبقات و المسافات الاجتماعية

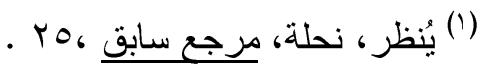


كالألقاب مثثلا. أمّا القسم الآخر من الإشاريات فميدانه رحب ويشــــ التحبـات وكل ما هو متصل بالجانب الحميمي في العلاقات كالتدليل والصفة أو صــلات الته القرابة، نحو : حبلى، زوجه، نجل، ابن...إلخ.

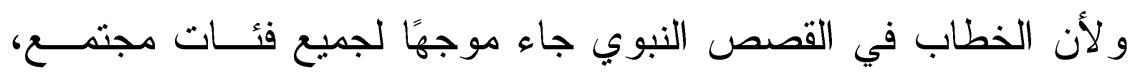

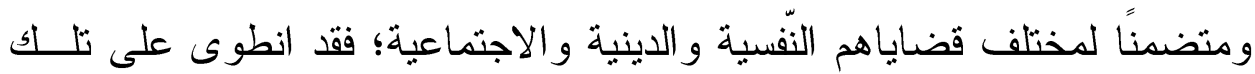
التز اكيب التي تخاطب كل فئات المجتمع صغير ا وكبير ا، غنيًا وفقير ا، فتـــاقش قضاياهم من جانب، وتبيّن لهم بلاغة الإعجاز النبوي التي فاقت بيانًا وشمولًا ما جاء على ألسنة شعر ائهم وكهّانهم في الجاهلية. ومن أمثلة توظيف تلك التر اكيب في القصة النبوية ،ما ورد في حديث الصدقة، فعَنْ أبي هُريْرَةَرضي الله عنه أنَّ

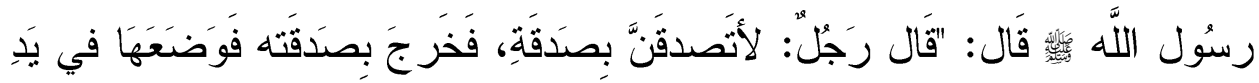

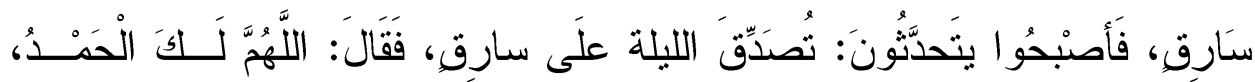

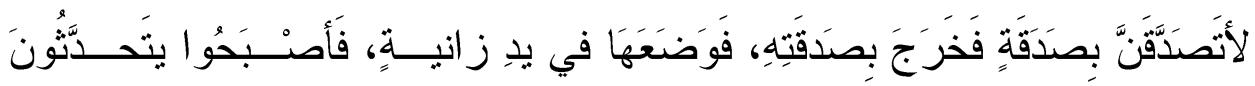

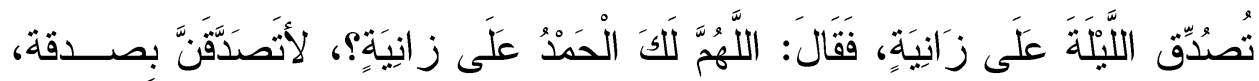

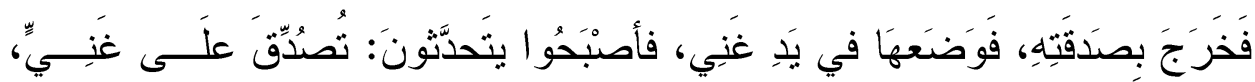

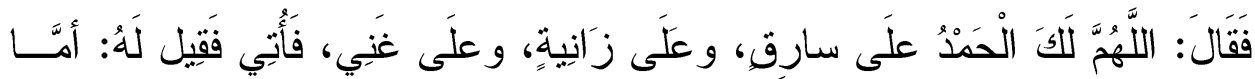

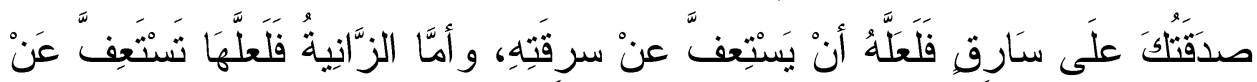

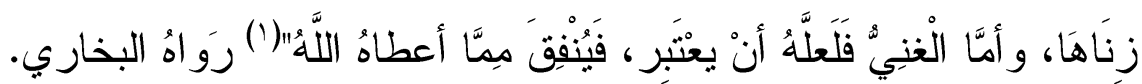

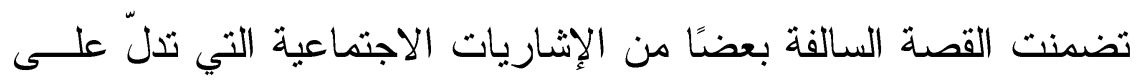
فئة اجتماعية وُسِت بالغالب عليها، وهي: (سارق)، و (ز انية)، و (غنيّ)، تلــك الفئات موجودة في المجتمع المسلم، وهي في الصــفة الأولـى و الثانية(ســـارق، زانية) تحمل دلالة غير مقبولة لدى مجتمع مؤمن بالله، ولهـــذا فــإن الصــفتين الإشاريتين داخل الحقل التداولي تحيل على مدلول تو اصلي يقتضــي العصــيان

$$
\text { صحيح البخاري:ابr|(1) جVדس، 1. }
$$


و الفسوق وهو ما يتتافى مع سلوكيات المجتمع وشــريعته، ويمكـنـ أن تصـــفـ الصيّيخ هنا ضمن الإشاريات غير الرسمية كونها صفة متبدّلة بتغير العمل ـ أمّا

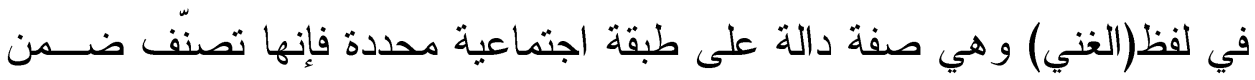
الإشاريات الرسمية.

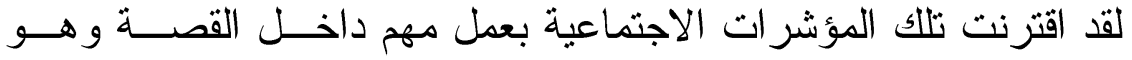
الصدقة، وهي صيغة إثـارية حملت صفة اجتماعية كذلك، هذا العمل و اجب ديني الرقيب فيه المولى -عزّ وجلّ - و الإخلاص و التحرّي في قبوله مطلب روحسي للمتصدق، كما أن الحرص على إعطائه لمستحقه هو غاية منشودة، فحينما وقعت الصدقة في يد السارق و الزانية و الغني، نازعت النفس الثكّ في القبول وبلـــوغ الحاجة، وبالتالي كانت النتيجة الندم على بذل الصدقة، لذلك جاء التسليم و الرضا

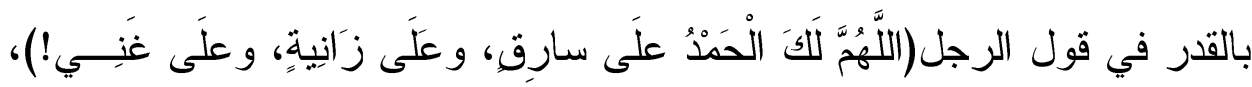
و هذا المعنى هو ما أدّته هذه المؤشرات في وظيفة لغوية تكاملية بسبب ما تؤول إليه من معان تحمل الرفض للسلوك المنوط بتلك الشخصيات، الــذي يمكـنـ أن

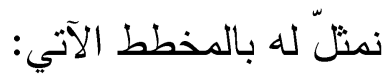

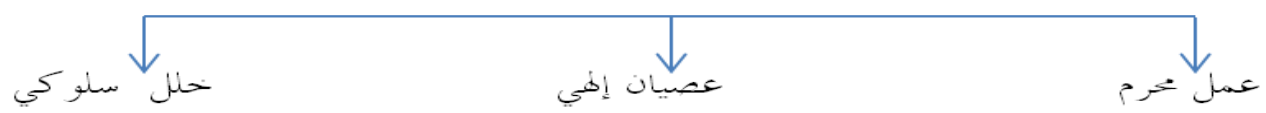

إشارة الكزانية

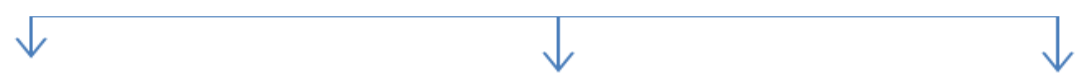

حلب سنو كي

عصيان إذي

عمل مخرم

إنشارة النهين 
و أثثاء هذا الندم يأتي البرهان للمتصدق في منامه مؤكدا له قبول صدقته ومبررا لهذا القبول بالأسباب التي قد تجعل السارق و الز انية يستعيضون بالصدقة عن فعل الحرام، وتجعل الغني يعتبر فيسعى للبذل. وتبرز أهمية هذه المؤشرات كونها جاءت موضع تبئير في لغة وأحداث القصة، فالسارق و الز انية و الغني هم فئات موجودة في المجتمع وينســاق علــى

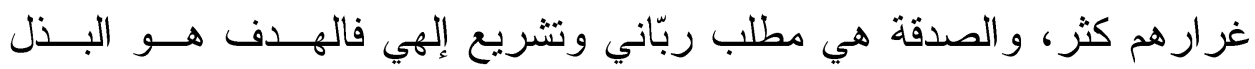
و السعي في الإصلاح و التو اصل داخل المجتمع و التماس الأســباب لـــللك قـدر إنـ المستطاع حتى و إن كان المستقبل ليس أهلا له. وبناء على ذلــــ فالملفوظــات (سارق، زانية، غني) هي محاور نسجت حولها أحـداث القـص، و اســتبدالها بغير ها أو حذفها سيشكل هدم للمعنى و يربك الهدف المقصود ومن ثـــ ينهـــار المبنى القصصي.

\section{ج ـ أثر الإشاريات في تحقيق مقاصد القصة النبوية:}

انطلاقًا من رأي اللغويين القائل بأن اللسانيات التداولية هي مجرد مفاهيم

معرفية تأسست لضبط وتقويم السلوك الإنساني أثناء عملية التو اصل اللغوي، فإن الدراسة هنا تسعى لجعل الإشاريات آلية تحليلية يمكن أن تكثف عن الإمكانيات التي تحتويها لغة القصّ في الخطاب النبوي أثناء العملية التو اصلية، بمعنى كيف يمكن توظيف المبحث الإشاري لتحليل العلامات اللغوية داخل القصص النبوي، وما مدى نجاح هذا الإجراء التحليلي في كثف المقاصد التبليغية للمخاطب متلقيًا مستمعاً أو قارئا؟ نجاج

رأينا فيما سبق أن الإشاريات بجميع أنواعها (شخصية، زمانية، مكانية، اجتماعية،) وخصائصها اللغوية و التركيبية قادت إلى عدة نتائج انعكس أثرها من خلال بنائها اللغوي على تجلية مضمون القصة وإيضاحه ، وبالتالي انطبع أثــره على المتلقي عند الاستعمال اللغوي لهذا النص الثريف. وولا خلاف حول هـذا 
الإعجاز اللغوي الذي ظهر أثناء تحليل القصص، فالنبي -صلى الله عليه وسلم-

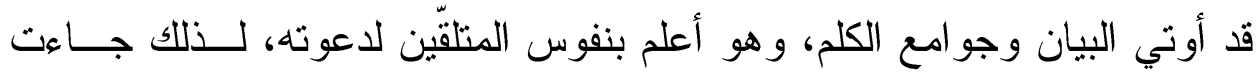
القصة في أقو اله موظفة لكل الإمكانات اللغوية التي تكفل إيصال ما بُعث به بفهم و اضح ونشويق محكوم.

لقد أدّت الإشاريات الموظفة في قصص الحديث النبوي - مــن وجهــة نظر الارس التداولي- دوراً فعالاً في إيضاح المقاصد وتحقيق الأهــداف مــن فئن القصص النبوي، وذللك بطريقة تعتمد على محورة الملفوظ الأهم فــي القصـــة، وجعله البؤرة التي ينسج حولها الحدث، ففي حين كانت القصة تعتمد على إيراز الشخصية بصفاتها و أفعالها، جاءت القصة مبرزة لهذا العنصر ومركزة عليه من

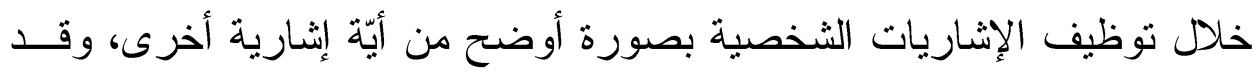
دعّم التكرار هذا الرأي وهو ما اتضح أثناء تحليل القصة المســماة بــــ جــرة الذهب) في موضع الإشاريات الشخصية('). و عندما كان الزمن هو المؤشر الذي يضبط الفكر الإقناعي لدى المتلقي؛ جاء البناء اللغوي للقصّ منتقيًا للتر اكيب ومقتفيًا سير الآلية التـي تخــدم هــذا

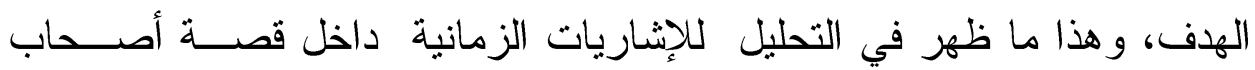
الغار (r)، حيث حققت القصة قناعة مفادها أنّ التوسل بصالح الأعمال و إن كانت ماضية ومعدودة هو أمر مشروع وقد جُنيت ثمر اته لدى من سبق. وفي قصة ( أصحاب السفينة) كان المؤشر المكاني هو الدلالة اللغويـــة

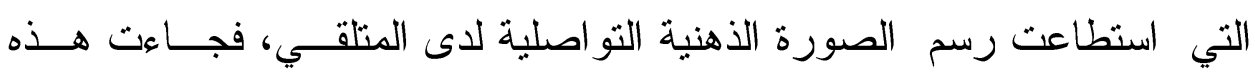
المؤشرات مر اكز إيضاح مهمة في القصة، ساهمت في تقريب التشبيه وربــ المعاني العقلية بمعاني محسوسة قرّبت الغاية وجلّت المقصود (ّ).

(') ينظر : تحليل القصة صفحة ه من هذا البحث. (r) ينظر : تحليل القصة صفحة 11 (r) من هذا البحث. (r) ينظر : تحليل القصة صفحة : 10 من هذا البحث. 
أمّا في الإشاريات الاجتماعية فقد اتضح من خلال تحليل قصة الصــدقة

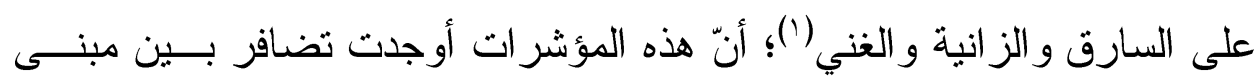
القصة ومضمونها، فخلقت قناعة ازدو اجية لدى المتلقي تؤمن بوجوب الصــدقة كتشريع إلهي وتدعو إلى البذل و الإصدلاح الاجتماعي حتى وإن كــان المسـتثبل غير مستحق في نظر المتصدق إلا أن التماس الأسباب قد تجعلها مقبولة تحقيقــا لهذا الو اجب ومنعًا لذرائع الشحّ. نخلص في هذا الفصل إلى أن الإشاريات التداولية هـــي أدوات لغويــة كثفت عن المحور المهم في القصة، كما أنها تكاد في كل قصة تركز على أحد العناصر الإشارية، حتى يغدو هذا العنصر يصبّ في إيضاح الهدف المرجو من القصة.

وقد بيّتت الإشاريات التداولية الآليّة التي قام عليها البنــاء القصصـي المرتكزة على النسج اللغوي بما يساعد في تجلّية المضمون و الكثف عن مقاصد

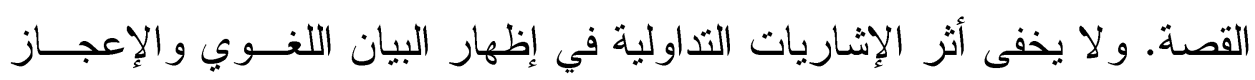

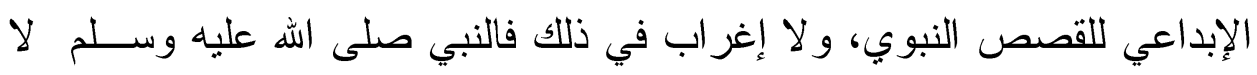
ينطق عن الهوى وهو سيّّ البشر بيانًا وبلاغة وفصاحة. 


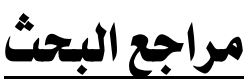

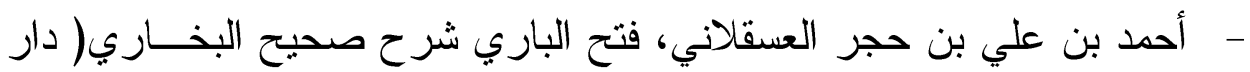

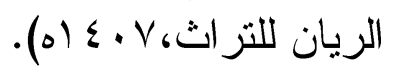

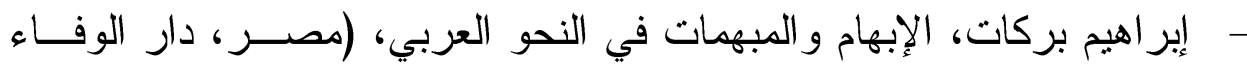

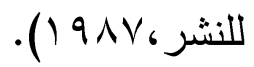

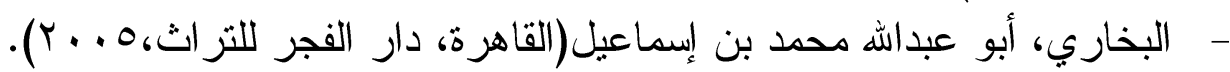

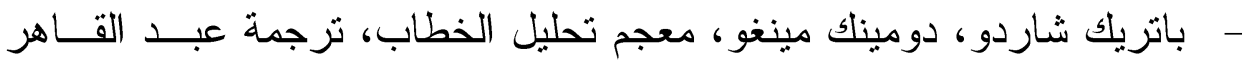

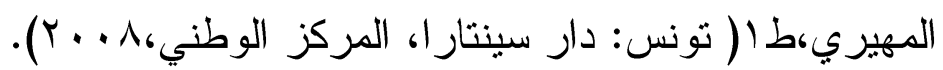

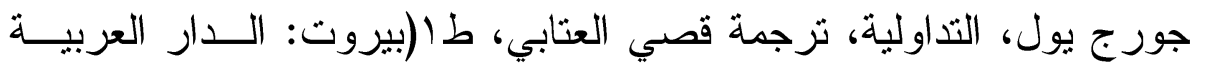

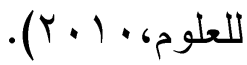

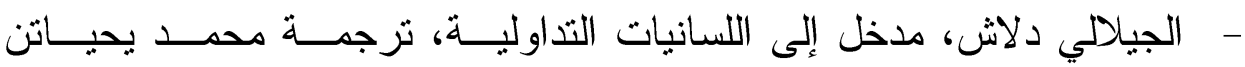

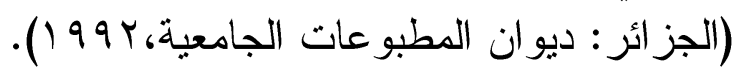

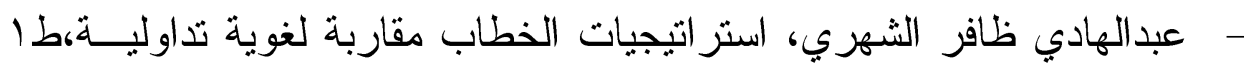

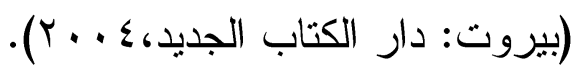

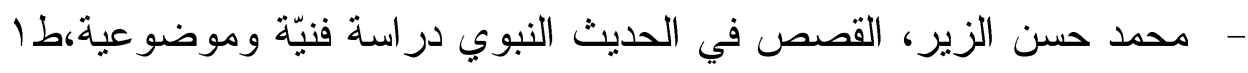

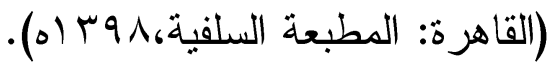

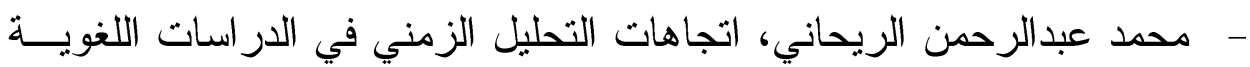

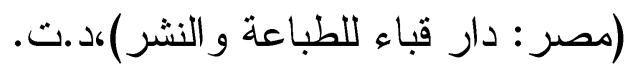

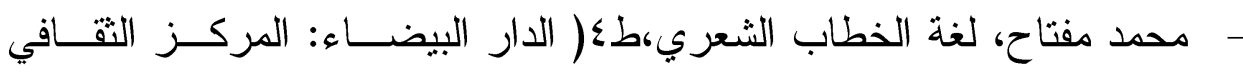

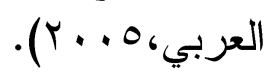

- محمود أحمد نحلة، آفاق جديدة في البحــث اللغـــوي المعاصر (مصــر : دار

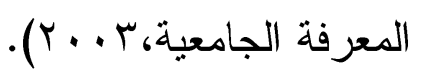

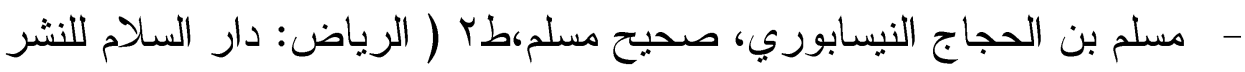

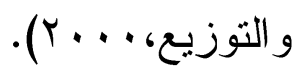

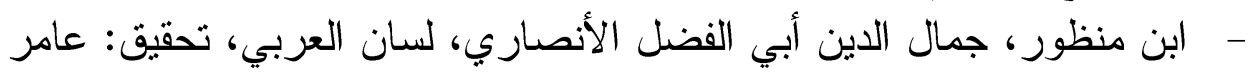

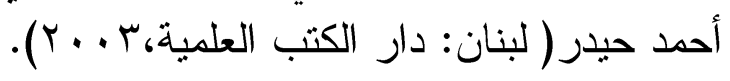

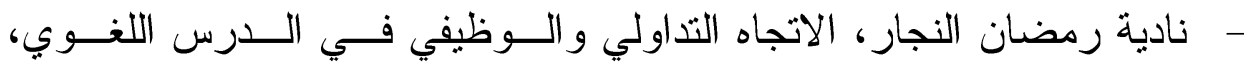

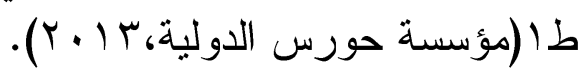

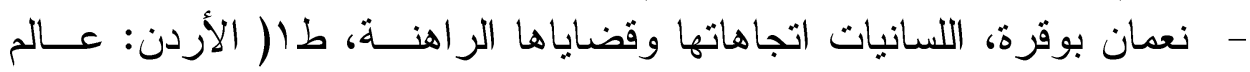

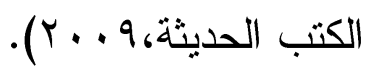

